\title{
Development and Selection of Risk Response Strategy in Projects: An Analysis of Recent Literature
}

\section{Carmen Nadia CIOCOIU, Emilian Cristian IRIMESCU and Vasile Emil ȘTEFAN}

The Bucharest University of Economic Studies, Bucharest, Romania

Correspondence should be addressed to: Vasile Emil ȘTEFAN; vasile.stefan@yahoo.com

Received date: 28 January 2019; Accepted date: 25 July 2019; Published date: 30 August 2019

Academic Editor: Petr Rehacek

Copyright (C) 2019. Carmen Nadia CIOCOIU, Emilian Cristian IRIMESCU and Vasile Emil ȘTEFAN. Distributed under Creative Commons CC-BY 4.0

\begin{abstract}
The development and selection of risk response strategies is a major phase in a project risk management process. The study focuses on recent literature with the purpose to analyze how this topic is found among the research concerns and the key trends in the area.The research focused on full length articles published in indexed academic journals and full proceedings papers indexed in Web of Science, as they can be considered as knowledge certified by peers and is a standard practice that enhances the reliability of results. We have restricted our search to a selected list of Web of Science indexed journals and conference proceedings. The selection used different combinations of keywords in title of articles, in Business and Management domain, and period 1990-April 2018.The selection of articles followed a two-step process: a keywords-based search using the Web of Science database and an analysis based on the researchers' interpretations of the abstracts/contents in order to decide whether these articles actually dealt with the topic. Additionally, the study identifies research gaps and proposes directions for future research.
\end{abstract}

Keywords: risk strategy, selection, project risk management, review

\section{Introduction}

How to develop and choose the most appropriate risk management strategy in projects is one of the constant concerns of project managers.
The development of risk response strategies is a distinct stage in the risk management process in projects and has different names from one methodology/standard to another. 
According to Project Management Institute (PMI, 2017), developing and selection of risk response strategies are carried out in two processes, respectively: plan risk responses and implement risk responses. On the other hand, ISO 31000:2018 indicates that risk treatment is one of the three major stages of risk management process (ISO, 2018).

A global consensus has been reached on the generic strategies that apply to project management, most of them taking over the classification proposed by the Project Management Institute (PMI) in the 11th chapter of PMBOK Guide. According to PMI (2017), risk can be not only negative, but also positive. Negative risks are always known as threat, and positive risks are also known as opportunities. The PMBOK Guide lists the possible risk responses for both types of risks. There are four possible strategies: avoid, transfer, mitigate and accept for negative risks and exploit, enhance, share and accept for positive risk.

In general, the application of one of the four generic strategies for risk management in projects is considered according to the probability and impact of each risk.

Determining which of the four risk response strategies is better to choose and its operationalization through concrete measures will depend on a variety of factors, including the project type and the risk appetite of organisation.

Řeháček (2017) and Řeháček (2019) perform a comparison of risk response strategies and point that the individual is responsible for the ongoing process of selecting and implementing optimal responses to any identified risk or opportunity.

Gericke, Klimentew and Blessing (2009) mention the lack of systematic support for the selection of appropriate risk management strategies in projects as a barrier in the success of project risk management. The authors develop a method to help risk managers in a better selection of risk treatment strategies based on the information about the cost of the measure proposed along with the probability and impact of risk treated.

In Gericke, Klimentew and Blessing's (2009) vision, risk identification and risk assessment are the subject of many research projects, while risk response strategies selection remains the responsibility of the risk manager who faces numerous obstacles and the only help is his experience.

In this context, the study tries to identify and analyze the scientific papers that directly address the development and selection of risk response strategies. The paper is organized as follows: after this short brief of the study, the second section is an overview of the research method and of the results. The third section deals with the results discussion. Conclusions are given at the end.

\section{Research Method and Results}

The literature from the year 1999 to 2018 has been reviewed in the present research. The time frame considered for the research is between January 1990 and April 2018. April 2018 was the moment when the research was started.

In order to collect the research papers for the review, a rigorous search was carried out using the Web of Science database. We have taken Web of Science into consideration because of its notoriety and importance in the academic environment. For our research, we have used as search criteria: the search engine, the time frame, the domain of the article, and the key words.

It has been found that only some research papers are directly associated with the concept of risk management strategies; therefore, in order to make a comprehensive review of literature, all the research papers related to the concepts of risk response, risk treatment and risk handling strategies have also been considered.

The keywords used for selecting the articles are: risk management strategies, 
risk response, risk treatment, risk handling strategies and risk handling project. All of them reflect the way risk is addressed in all of the industries and also in social and other activities.

Further, it has been found that before 1999 the number of identified articles was very reduced. Considering the search criteria mentioned, we have identified only 5 articles, written by Blankenburg (1979), Hanna (1985), Dardis (1985 and 1983) and Puto et al. (1985).

After final selection, the research papers were tabulated and classified on the basis of:

- Keywords

- Year of publication

- Domains

- Research methods

The selection of articles was realized only in two main domains. There are many domains related to the key words used and generally to risk management, but our research is focused on articles classified in business and management.

Only the papers appearing in journals and conference proceedings were included for the review of literature, as they represented a higher level of research. Therefore, books, meeting abstracts, editorial materials and letters, were excluded from the analysis.
The first search based on risk management strategies keywords in the article title generated 178 articles. Selecting from them the articles related to business and management, and after the designated frame time, we have found 20 titles. We have excluded from the result 3 books, and at the end of the search remains 17 titles.

The search after risk response keywords in the article title generated 166 articles. After we have considered only the business and management articles, in the designated time frame, we have counted 9 articles. For this search we haven't found books revealed.

There were found 65 results for risk treatment keywords. Refined after business and management domains, and after the time frame, we have found only 3 articles. A book was eliminated, and only 2 titles left.

Searching after risk handling strategies keywords, we have obtained at the beginning only 2 titles. One of the books was published in 2012, but neither of them was related with business and management domain. So, for these keywords we had zero results.

Also for risk handling in projects we have had zero results, based only on the general search in the Web of Science.

The final results were verified for double titles, and the final number of articles based on the selection was 28. The results are presented in Table 1.

Table 1: List of Selected Papers

\begin{tabular}{|c|l|l|l|c|}
\hline No & \multicolumn{1}{|c|}{ Author } & \multicolumn{1}{|c|}{ Title } & Journal/Proceedings & Year \\
\hline 1 & $\begin{array}{l}\text { Stewart, Fenner L.; } \\
\text { Cioni, Anthony G. }\end{array}$ & $\begin{array}{l}\text { Holistic Security Risk } \\
\text { Management Strategies for E\&Ps: } \\
\text { Optimizing Performance by } \\
\text { Reducing Surface Risk }\end{array}$ & $\begin{array}{l}\text { Journal of World Energy } \\
\text { Law \& Business }\end{array}$ & 2018 \\
\hline 2 & $\begin{array}{l}\text { Zuo, Fei; Zhang, } \\
\text { Kailing }\end{array}$ & $\begin{array}{l}\text { Selection of Risk Response Actions } \\
\text { with Consideration of Secondary } \\
\text { Risks }\end{array}$ & $\begin{array}{l}\text { International Journal of } \\
\text { Project Management }\end{array}$ & 2018 \\
\hline 3 & $\begin{array}{l}\text { Andrea; Serences, } \\
\text { Peter; Toth, Marian }\end{array}$ & $\begin{array}{l}\text { Marmers' Risk Perception and Risk } \\
\text { Management Strategies in Slovak }\end{array}$ & $\begin{array}{l}\text { Managerial Trends in the } \\
\text { Development of } \\
\text { Enterprises In } \\
\text { Globalization Era }\end{array}$ & 2017 \\
\hline
\end{tabular}




\begin{tabular}{|c|c|c|c|c|}
\hline 4 & $\begin{array}{l}\text { Yoon, Jiho; Yildiz, } \\
\text { Hakan; Talluri, } \\
\text { Srinivas } \\
\end{array}$ & $\begin{array}{l}\text { Risk Management Strategies in } \\
\text { Transportation Capacity } \\
\text { Decisions: An Analytical Approach }\end{array}$ & $\begin{array}{l}\text { Journal of Business } \\
\text { Logistics }\end{array}$ & 2016 \\
\hline 5 & Pan, Shuang-Qing & $\begin{array}{l}\text { The Risk Management Strategies } \\
\text { of Financial Liberalization in } \\
\text { China }\end{array}$ & $\begin{array}{l}\text { Proceedings of the } 2016 \\
\text { International Conference } \\
\text { on Management Science } \\
\text { and Management } \\
\text { Innovation }\end{array}$ & 2016 \\
\hline 6 & $\begin{array}{l}\text { Soofifard, Rahman; } \\
\text { Bafruei, Morteza } \\
\text { Khakzar }\end{array}$ & $\begin{array}{l}\text { An Optimal model for Project Risk } \\
\text { Response Portfolio Selection } \\
\text { (P2RPS) (Case study: Research } \\
\text { Institute of Petroleum Industry) }\end{array}$ & $\begin{array}{l}\text { Iranian Journal of } \\
\text { Management Studies }\end{array}$ & 2016 \\
\hline 7 & Zhang, Yao & $\begin{array}{l}\text { Selecting Risk Response Strategies } \\
\text { Considering Project Risk } \\
\text { Interdependence }\end{array}$ & $\begin{array}{l}\text { International Journal of } \\
\text { Project Management }\end{array}$ & 2016 \\
\hline 8 & $\begin{array}{l}\text { Wu, Dengsheng; } \\
\text { Dai, Qianzhi; Zhu, } \\
\text { Xiaoqian }\end{array}$ & $\begin{array}{l}\text { Measuring the Effect of Project } \\
\text { Risks Based on Shapley Value for } \\
\text { Project Risk Response }\end{array}$ & $\begin{array}{l}\text { Promoting Business } \\
\text { Analytics and Quantitative } \\
\text { Management of } \\
\text { Technology: 4th } \\
\text { International Conference } \\
\text { on Information Technology } \\
\text { and Quantitative } \\
\text { Management (ITQM 2016), } \\
\text { Book Series: Procedia } \\
\text { Computer Science, Volume: } \\
91 \\
\end{array}$ & 2016 \\
\hline 9 & $\begin{array}{l}\text { Mondlane, Avelino; } \\
\text { Hasson, Karin; } \\
\text { Popov, Oliver }\end{array}$ & $\begin{array}{l}\text { E-Governance and Natural } \\
\text { Hazards in Mozambique: A } \\
\text { Challenge for Backasting Method } \\
\text { Used for Flood Risk Management } \\
\text { Strategies }\end{array}$ & $\begin{array}{l}\text { Emerging Issues and } \\
\text { Prospects in African E- } \\
\text { Government. Book Series: } \\
\text { Advances in Electronic } \\
\text { Government Digital Divide } \\
\text { and Regional Development } \\
\end{array}$ & 2015 \\
\hline 10 & $\begin{array}{l}\text { Gjerald, Olga; } \\
\text { Lyngstad, Hallvor }\end{array}$ & $\begin{array}{l}\text { Service Risk Perceptions and Risk } \\
\text { Management Strategies in } \\
\text { Business-to-Business Tourism } \\
\text { Partnerships }\end{array}$ & $\begin{array}{l}\text { Tourism Management } \\
\text { Perspectives }\end{array}$ & 2015 \\
\hline 11 & $\begin{array}{l}\text { Zhang, Yao; Fan, } \\
\text { Zhi-Ping }\end{array}$ & $\begin{array}{l}\text { An Optimization Method for } \\
\text { Selecting Project Risk Response } \\
\text { Strategies }\end{array}$ & $\begin{array}{l}\text { International Journal of } \\
\text { Project Management }\end{array}$ & 2013 \\
\hline 12 & $\begin{array}{l}\text { Fang, Chao; Marle, } \\
\text { Franck; Xie, Min }\end{array}$ & $\begin{array}{l}\text { An Integrated Framework for Risk } \\
\text { Response Planning under } \\
\text { Resource Constraints in Large } \\
\text { Engineering Projects }\end{array}$ & $\begin{array}{l}\text { IEEE Transactions on } \\
\text { Engineering Management }\end{array}$ & 2013 \\
\hline 13 & $\begin{array}{l}\text { Sofyalioglu, } \\
\text { Cigdem; Kartal, } \\
\text { Burak }\end{array}$ & $\begin{array}{l}\text { The Selection of Global Supply } \\
\text { Chain Risk Management Strategies } \\
\text { by Using Fuzzy Analytical } \\
\text { Hierarchy Process - A case from } \\
\text { Turkey }\end{array}$ & $\begin{array}{l}\text { 8th International Strategic } \\
\text { Management Conference, } \\
\text { Book Series: Procedia } \\
\text { Social and Behavioral } \\
\text { Sciences, Volume: } 58 \\
\end{array}$ & 2012 \\
\hline 14 & $\begin{array}{l}\text { Polak, George G.; } \\
\text { Rogers, David F.; } \\
\text { Sweeney, Dennis J. }\end{array}$ & $\begin{array}{l}\text { Risk Management Strategies via } \\
\text { Minimax Portfolio Optimization }\end{array}$ & $\begin{array}{l}\text { European Journal of } \\
\text { Operational Research }\end{array}$ & 2010 \\
\hline
\end{tabular}




\begin{tabular}{|c|c|c|c|c|}
\hline 15 & $\begin{array}{l}\text { Prelipcean, } \\
\text { Gabriela; } \\
\text { Boscoianu, Mircea }\end{array}$ & $\begin{array}{l}\text { An Analysis of the Risk } \\
\text { Management Strategies in Venture } \\
\text { Capital Investments }\end{array}$ & $\begin{array}{l}\text { 16th International } \\
\text { Conference the } \\
\text { Knowledge-Based } \\
\text { Organization: Economic, } \\
\text { Social And Administrative } \\
\text { Approaches to the } \\
\text { Knowledge-Based } \\
\text { Organization, Conference } \\
\text { Proceedings 2 }\end{array}$ & 2010 \\
\hline 16 & $\begin{array}{l}\text { Arshad, Noor } \\
\text { Habibah; } \\
\text { Mohamed, Azlinah; } \\
\text { Mansor, Ruzaidah }\end{array}$ & $\begin{array}{l}\text { The Effects of Implementing } \\
\text { Organizational Structural and Risk } \\
\text { Management Strategies in } \\
\text { Information System Projects }\end{array}$ & $\begin{array}{l}\text { MICBE '09: Proceedings Of } \\
\text { The 10th WSEAS } \\
\text { International Conference } \\
\text { on Mathematics and } \\
\text { Computers in Business and } \\
\text { Economics }\end{array}$ & 2009 \\
\hline 17 & $\begin{array}{l}\text { Gericke, Kilian; } \\
\text { Klimentew, Lars; } \\
\text { Blessing, Lucienne }\end{array}$ & $\begin{array}{l}\text { Measure and Failure Cost } \\
\text { Analysis: Selecting Risk Treatment } \\
\text { Strategies }\end{array}$ & $\begin{array}{l}\text { ICED } 09 \text { - The 17th } \\
\text { International Conference } \\
\text { on Engineering Design, Vol } \\
\text { 3: Design Organization and } \\
\text { Management }\end{array}$ & 2009 \\
\hline 18 & $\begin{array}{l}\text { Ji, Guojun; Zhu, } \\
\text { Caihong }\end{array}$ & $\begin{array}{l}\text { Study on Supply Chain Disruption } \\
\text { Risk Management Strategies and } \\
\text { Model }\end{array}$ & $\begin{array}{l}2008 \text { 5th International } \\
\text { Conference on Service } \\
\text { Systems and Service } \\
\text { Management. vols } 1 \text { and 2, } \\
\text { Book Series: International } \\
\text { Conference on Service } \\
\text { Systems and Service } \\
\text { Management }\end{array}$ & 2008 \\
\hline 19 & $\begin{array}{l}\text { Manuj, Ila; } \\
\text { Mentzer, John T. }\end{array}$ & $\begin{array}{l}\text { Global Supply Chain Risk } \\
\text { Management Strategies }\end{array}$ & $\begin{array}{l}\text { International Journal of } \\
\text { Physical Distribution \& } \\
\text { Logistics Management }\end{array}$ & 2008 \\
\hline 20 & $\begin{array}{l}\text { Sharmak, Wael; } \\
\text { Schapke, Sven-Eric; } \\
\text { Scherer, Raimar J. }\end{array}$ & $\begin{array}{l}\text { Risk Treatment Templates for } \\
\text { Configurable Reference Modeling } \\
\text { in the Construction Industry }\end{array}$ & \begin{tabular}{|l|} 
Pervasive Collaborative \\
Networks. PRO-VE 2008. \\
IFIP - The International \\
Federation for Information \\
Processing, vol 283. \\
Springer, Boston, MA \\
\end{tabular} & 2008 \\
\hline 21 & $\begin{array}{l}\text { Liu, Huizhong; } \\
\text { Zheng, Maolin }\end{array}$ & $\begin{array}{l}\text { Analysis on Integrated Risk } \\
\text { Response Planning in Large } \\
\text { Projects }\end{array}$ & $\begin{array}{l}\text { Proceedings of the 3rd } \\
\text { International Conference } \\
\text { on Product Innovation } \\
\text { Management }\end{array}$ & 2008 \\
\hline 22 & Ji, Guojun & $\begin{array}{l}\text { Ecological Supply Chains } \\
\text { Performance Evaluation and } \\
\text { Disruption Risk Management } \\
\text { Strategies }\end{array}$ & $\begin{array}{l}\text { Proceedings of The } 2008 \\
\text { International Conference } \\
\text { on E-Risk Management } \\
\text { (Icerm 2008) }\end{array}$ & 2008 \\
\hline 23 & $\begin{array}{l}\text { Wang, Yuqi; Hu, } \\
\text { Yunquan }\end{array}$ & $\begin{array}{l}\text { A Study on Risk Response Model } \\
\text { of Oil \& Gas Exploration Project's } \\
\text { Risk Management }\end{array}$ & $\begin{array}{l}\text { ISCRAM CHINA 2007: } \\
\text { Proceedings of the Second } \\
\text { International Workshop on } \\
\text { Information Systems for } \\
\text { Crisis Response and } \\
\text { Management }\end{array}$ & 2007 \\
\hline 24 & $\begin{array}{l}\text { Mohammed, M. A.; } \\
\text { Ortmann, G. F.; } \\
\text { Ferrer, S. R. D. }\end{array}$ & $\begin{array}{l}\text { Risk Management Strategies on } \\
\text { Small-Scale Commercial Farms in } \\
\text { Three Zobatat of Eritrea }\end{array}$ & $\begin{array}{l}\text { South African Journal of } \\
\text { Economic and } \\
\text { Management Sciences }\end{array}$ & 2006 \\
\hline
\end{tabular}




\begin{tabular}{|l|l|l|l|l|}
\hline 25 & Gao, Hongyan & $\begin{array}{l}\text { Risk Management Strategies for } \\
\text { Film-Making Companies }\end{array}$ & $\begin{array}{l}\text { Proceedings of the 2006 } \\
\text { International Conference } \\
\text { on Management Science } \\
\text { And Engineering }\end{array}$ & 2006 \\
\hline 26 & $\begin{array}{l}\text { Qi, BK; Yan, } \\
\text { Changjun; } \\
\text { Mortimer, Stephen }\end{array}$ & $\begin{array}{l}\text { Risk Management Strategies of } \\
\text { Chinese Construction Industry } \\
\text { International Conference } \\
\text { on Construction \& Real } \\
\text { Estate Management }\end{array}$ & 2004 \\
\hline 27 & $\begin{array}{l}\text { Ben-David, Itzhak; } \\
\text { Raz, T. }\end{array}$ & $\begin{array}{l}\text { An Integrated Approach for Risk } \\
\text { Response Development in Project } \\
\text { Planning }\end{array}$ & $\begin{array}{l}\text { lournal of the Operational } \\
\text { Research Society }\end{array}$ & 2001 \\
\hline $\begin{array}{l}\text { Baron, Michelle M.; } \\
\text { Paté-Cornell, } \\
\text { Marie-Elisabeth } \\
\text { Lucienne }\end{array}$ & $\begin{array}{l}\text { Designing Risk-Management } \\
\text { Strategies for Critical Engineering } \\
\text { Systems }\end{array}$ & $\begin{array}{l}\text { IEEE Transactions on } \\
\text { Engineering Management }\end{array}$ & 1999 \\
\hline
\end{tabular}

Of the 28 papers selected, 14 are articles, and the rest are proceedings papers.

A first quantitative result of the selection is presented in Table 2.

The first keywords used risk management strategies had a share of more than $60 \%$ in the total results, followed by risk response with $32.14 \%$ and risk treatment with $7.14 \%$.

Keywords risk handling strategies and risk handling in projects did not generate any search results in the title of the articles.

Table 2: Distribution of Search Results Using Keywords in the Title of the Papers

\begin{tabular}{|l|c|c|}
\hline \multicolumn{1}{|c|}{ Keywords } & Search Results & \% from Total Results \\
\hline risk management strategies & 17 & $60.71 \%$ \\
\hline risk response & 9 & $32.14 \%$ \\
\hline risk treatment & 2 & $7.14 \%$ \\
\hline risk handling strategies & 0 & $0.00 \%$ \\
\hline risk handling in projects & 0 & $0.00 \%$ \\
\hline Total & $\mathbf{2 8}$ & $\mathbf{1 0 0 . 0 0 \%}$ \\
\hline
\end{tabular}

Source: authors calculation based on Web of Science data

Regarding the distribution per year of the results, data are summarized in Table 3.

Table 3: Distribution of Search Results Using Keywords in the Title of the Papers per Year

\begin{tabular}{|c|c|c|}
\hline & Search Results & \% from Total Results \\
\hline 1999 & 1 & $3.57 \%$ \\
\hline 2001 & 1 & $3.57 \%$ \\
\hline 2004 & 1 & $3.57 \%$ \\
\hline 2006 & 2 & $7.14 \%$ \\
\hline 2007 & 1 & $3.57 \%$ \\
\hline 2008 & 5 & $17.86 \%$ \\
\hline 2009 & 2 & $7.14 \%$ \\
\hline 2010 & 2 & $7.14 \%$ \\
\hline 2012 & 1 & $3.57 \%$ \\
\hline 2013 & 2 & $7.14 \%$ \\
\hline 2015 & 2 & $7.14 \%$ \\
\hline
\end{tabular}




\begin{tabular}{|c|c|c|}
\hline 2016 & 5 & $17.86 \%$ \\
\hline 2017 & 1 & $3.57 \%$ \\
\hline 2018 & 2 & $7.14 \%$ \\
\hline Total & $\mathbf{2 8}$ & $\mathbf{1 0 0 . 0 0 \%}$ \\
\hline
\end{tabular}

Source: authors calculation based on Web of Science data

Studying the evolution in time of the numbers of the articles we have remarked two peaks, in 2008 and 2016, as the number of publications in these years is maximum, that is, 17 . Each peak has results above $17 \%$ share from the total amount of articles. Also we have remarked that we had few years with zero results, such as 2002, 2003 and 2014.

Regarding the distribution of the articles on activity domains, there are two of them with a higher share than the rest: project management, with $25 \%$, and supply chain, with $17.86 \% \quad$ (Table 4). Project management, being a tool for general approaching for different activities, is normal to have a higher share. Excepting project management, supply chain is a result that underlines a specific interest for a particular domain.

Table 4: Distribution of Articles by Domains

\begin{tabular}{|l|c|c|}
\hline \multicolumn{1}{|c|}{ Domain } & Articles & \% from Total Articles \\
\hline Agriculture & 2 & $7.14 \%$ \\
\hline Constructions & 3 & $10.71 \%$ \\
\hline Critical infrastructure & 2 & $7.14 \%$ \\
\hline Finance & 3 & $10.71 \%$ \\
\hline Gas and oil & 2 & $7.14 \%$ \\
\hline IT\&C & 1 & $3.57 \%$ \\
\hline Production & 1 & $3.57 \%$ \\
\hline Project management & 7 & $25.00 \%$ \\
\hline Services Total & 2 & $7.14 \%$ \\
\hline Supply chain & 5 & $17.86 \%$ \\
\hline
\end{tabular}

Source: authors calculation based on Web of Science data

We also analyzed the results from the research method standpoint. We have identified five categories, which are distributed according to Table 5.

Table 5: Research Methodologies in Articles

\begin{tabular}{|l|c|c|}
\hline \multicolumn{1}{|c|}{ Research Method } & Articles & \% from Total Articles \\
\hline analytical literature review & 8 & $28.57 \%$ \\
\hline case study & 13 & $46.43 \%$ \\
\hline interview & 3 & $10.71 \%$ \\
\hline survey & 2 & $7.14 \%$ \\
\hline other & 2 & $7.14 \%$ \\
\hline Total & $\mathbf{2 8}$ & $\mathbf{1 0 0 . 0 0 \%}$ \\
\hline
\end{tabular}

Source: authors calculation based on Web of Science data 
As we can observe in Table 5, case studies represent the most used method in developing or confirming the theoretical models $(46 \%$ of the articles are based on case studies). Next important tool for research is analytical literature review. We understand by analytical literature review articles which develop a theoretical model based only on literature review. The percentage of the usage of this method is $28 \%$.

In terms of research results, we have identified that more than $57.14 \%$ of the results are based on a model: decision, conceptual, linear programing, mathematic, optimization models, and method related models (Table 6).

Table 6: Number of Items Using Models

\begin{tabular}{|c|c|c|}
\hline \multicolumn{1}{|c|}{ Result } & Articles & $\begin{array}{c}\text { \% from Total } \\
\text { Articles }\end{array}$ \\
\hline Model & 16 & $57.14 \%$ \\
\hline Other results & 12 & $42.86 \%$ \\
\hline Total & $\mathbf{2 8}$ & $\mathbf{1 0 0 . 0 0 \%}$ \\
\hline
\end{tabular}

Source: authors calculation based on Web of Science data

\section{Discussions}

As we can observe from the above mentioned results, we have identified that the main term used by authors such as Zuo (2018), Baron (1999), Qi (2004), Gao (2006), Mohammed (2006), Ji (2008), Manuj (2008), Arshad (2009), Prelipcean (2010), Polak (2010), Sofyalioglu (2012), Gjerald (2015), Mondlane (2015), Pam (2016), Yoon (2016), Bohacikova (2017), Stewart (2018) is risk management strategies $(60.71 \%$ of the results). Basically, that means that all those papers intend to define a pattern or a general approach regarding the risk response.

Another result refers to the year distribution of the articles. In 2008 (with articles by Ji (2008), Manuj (2008), Liu (2008), Sharmak (2008)) and 2016 (with articles by Yoon (2016), Pan (2016), Soofifard (2016), Zhang (2016), Wu (2016)) we have observed for each year a peek represented by $17.86 \%$ from all the articles. Both of the years are very important related to events that occurred in that period. In 2008 we had the major economic crises, and in 2016 we also had significant socio political problems regarding international security.
The second result is that the number of articles is increasing, due to the increasing number of socio economic problems (from 1990 to nowadays).

The third result shows that $25 \%$ of the articles (Zuo, 2018; Soofifard, 2016; Zhang, 2016; Wu, 2016; Zhang 2013; Fang 2013; Liu 2008; Ben-David 2001; Gericke, 2009) are focused on projects, and not on a specific and recurrent activity. This result can be related to the term strategies present as the first result.

Regarding the research method used by authors, $46.43 \%$ of articles are based on case studies. This aspect reveals a very practical side of the research made by Mondlane (2015), Gjerald (2015), Sofialyoglu (2012), Polak (2010), Ji (2008), Baron (1999), Zuo (2018), Soofifard (2016), Zhang (2016), Wu (2016), Zhang (2013), Fang (2013), Ben-David (201).

The fifth result shows that $57.14 \%$ of the articles, written by Stewart (2018), Yoon (2016), Gjerald (2015), Polak (2010), Ji (2008), Baron (1999), Zuo (2018), Soofifard (2016), Zhang (2016), Wu (2016), Zhang (2013), Fang (2013), Liu (2008), Wang (2007), Ben-David (2001), Gericke (2009), end with a model regarding 
risk response. This result can be related with the result regarding the case studies.

From the analyzed papers, we can observe that the authors tried to have a general approach, but based on specific cases. The general approach is highlighted by considering the topics based on project management theory. Same time, the specific case studies help the authors in order to identify the patterns and the models of addressing the risk.

Even most of the articles are based on specific cases; the research methodology itself varies from simple literature review articles to advanced research techniques (for example AHP). Such an example is Sofyaliglo et al. (2012) who used Fuzzy Analytic Hierarchy Process to analyze the selection of global supply chain risk management strategies.

Generally, the results of the papers have tried to have some practical features. For example, Stewart et al. (2018) provided in the article a clear list of recommendations for how to reduce security risks for the exploration and production companies. Same way, Pan (2016) presented a list of strategies in order to address financial risks. Another example is Yoon et al. (2016), who, based on a numeric model, extracted some managerial implications regarding risk management strategies in transportation capacity decisions. So even if we have a numeric approach or a theoretical model, the articles' results are generally practical and applicable in risk management.

Besides the main pattern, there are cases when the authors present only a few general observations about the topic, but do not develop a model of risk management selection strategy. An example is the article called "Service Risk Perceptions and Risk Management Strategies in Business-to-Business Tourism Partnerships" written by Gjerald et al. (2015).

\section{Conclusions and Future Research Directions}

This paper analyses the literature on risk management strategies in projects and provides the summary of findings of 28 research papers published in journals and conference proceedings.

From the results presented in the previous chapter, we can identify some patterns and answers regarding two research questions.

The first research question of the authors was "How has the business literature after 1990 researched development and selection of risk response strategy in projects?". The main conclusion is that the subject is included in many papers published in various fields of study, but the number of papers dealing exclusively with the formulation of risk management strategies is relatively low.

There are some cases where the research is based mostly on literature review (28.57\%), despite the fact that research based on practical facts could be more interesting.

Regarding the second research question, "How could results from the literature help to develop and select the proper risk management strategies in projects?", we can observe that the majority of articles try to provide some practical methods to address the topic. Even if we discuss about some recommendations, or a numeric model with practical applicability, or a theoretical model, the majority of the authors provide a practical tool for helping the economic or social environment to address risks.

"Project management", "case studies" and "models" are three keywords which best describe the results of our research, and also the main directions of the papers found and analyzed by un until now.

These three keywords are also connected to the practical side of the research. This practical side was and is very important in moving from the theoretical side of the risk management, to the practical one. The results from the literature offer support in developing and selecting the proper risk management strategies in the real economic and business activity. 
The research activity related to risk management is having an increasing trend that may continue in the next period. This increasing trend reflects and also confirms the risks from the economic and social environment, and stands for a better mitigation of them.

More than that, because of the existing risks from the real economic and social environment, the increasing trend of this type of research must be kept and sustained by the academic environment.

This study is the first insight into the literature regarding the development of risk management strategies in projects. In further research, the authors propose to carry out a deeper analysis of the identified works in order to build a map of the concerns in the field according to a set of criteria that help the managers to make a choice of the appropriate strategies.

\section{Acknowledgment}

This paper was co-financed by the Bucharest University of Economic Studies during the PhD program.

\section{References}

1. Gericke, K., Klimentew, L. and Blessing, L. (2009). Measure and failure cost analysis: selecting risk treatment strategies. 61-72, Proceedings of ICED 09, the 17th International Conference on Engineering Design, Vol. 3, Design Organization and Management, Palo Alto, CA, USA, 24-27.08.2009

2. Gjerald, O. and Lyngstad, H. (2015), 'Service Risk Perceptions and Risk Management Strategies in Business-toBusiness Tourism Partnerships,' Tourism Management Perspectives, 13, 7-17.

3. Hopkin, P. (2018) 'Fundamentals of Risk Management: Understanding, Evaluating and Implementing Effective Risk
Management, $5^{\text {th }}$ edition,' Kogan Page Publishers, New York.

4. ISO (2018), ISO 31000:2018 Risk Management Guidelines

5. Pan, S. (2016) 'The Risk Management Strategies of Financial Liberalization in China,' Proceeding of the 3rd International Conference on Management Science and Management Innovation (MSMI 2016), 1314 August 2016, Guilin, China, 135-137.

6. PMI (2017), A guide to the project management body of knowledge" (PMBOK Guide), 6th edition, Published by: Project Management Institute, Inc., Pennsylvania.

7. Řeháček, P. (2019) 'Risk Management as an Instrument of the Effectiveness of Quality Management System,' Quality Access to Success, 20 (168), 93-96.

8. Řeháček, P. (2017) 'Risk Management Standards for Project Management,' International Journal of Advanced and Applied Sciences, 4(6), 1-13.

9. Sofyalioglu, C. and Kartal, B. (2012), 'The Selection of Global Supply Chain Risk Management Strategies by Using Fuzzy Analytical Hierarchy Process a Case from Turkey,' Procedia - Social and Behavioral Sciences, 58, 1448-1457.

10. Stewart, F. and Cioni, A. (2018), 'Holistic Security Risk Management Strategies for E\&Ps: Optimizing Performance by Reducing Surface Risk,' Journal of World Energy Law and Business, 11(1), 49-84.

11. Yoon, J., Yildiz, H. and Talluri, S. (2016), 'Risk Management Strategies in Transportation Capacity Decisions: An Analytical Approach,' Journal of Business Logistics, 37(4), 364-381. 